\title{
A preliminary evaluation of the effects of comprehensive rehabilitation on emotional well-being and quality of life in female patients with osteoarthritis
}

\author{
Wstępna ocena wpływu kompleksowej rehabilitacji na stan emocjonalny i jakość \\ życia pacjentek z chorobą zwyrodnieniową stawów
}

\section{Ewa Gaszewska, Krystyna Księżopolska-Orłowska, Olga Krasowicz-Towalska, Marcin Kożuchowski, Teresa Sadura-Sieklucka}

Clinic of Rehabilitation in Rheumatology Prof. Eleonora Reicher's Institute of Rheumatology in Warsaw,

Klinika Rehabilitacji Reumatologicznej Instytutu Reumatologii im. prof. dr hab. med. Eleonory Reicher w Warszawie

Key words: osteoarthritis, quality of life, emotional well-being, comprehensive rehabilitation.

Słowa kluczowe: choroba zwyrodnieniowa stawów, jakość życia, stan emocjonalny, kompleksowa rehabilitacja.

\section{Sum mary}

Objectives: To evaluate the effects of comprehensive rehabilitation on psychological and emotional well-being as well as on the quality of life in female patients with multiple degenerative lesions of the musculoskeletal system.

Material and methods: Thirty-one female patients with multiple-site musculoskeletal degenerative lesions were included in the study. Two rehabilitation strategies were used: group I $(n=18)$ underwent conventional physiotherapy and kinesiotherapy (aquatic exercises), whereas group II ( $n=13)$ underwent cryotherapy and kinesiotherapy. Each patient was examined three times: prior to therapy, 4 weeks into her rehabilitation course, and 3 months after its completion. The GHQ-28 questionnaire was used to assess the patients' psychological status and the SF-36 was used to assess the quality of life and daily subjective pain severity. The results were used in a statistical analysis. Results: According to the subjective pain assessment questionnaire, both groups were comparable in terms of reduction in pain severity (\%). Pain alleviation was observed in both study groups also based on the SF-36, and reduced pain severity persisted in both groups at 3 months following therapy completion. According to GHQ-28 results, the psychological and emotional well-being of patients after rehabilitation, treated with either aquatic exercises (group I) or cryotherapy (group II), clearly improved. In group I, there were clear effects immediately following treatment, with a reduced improvement after 3 months, though not down to the baseline level, whereas in group II a clear and sustained health improvement was observed.

\section{Streszczenie}

Cel pracy: Ocena wpływu kompleksowej rehabilitacji na kondycję psychiczną i emocjonalną oraz na jakość życia pacjentek z wielomiejscowymi zmianami zwyrodnieniowymi w układzie ruchu.

Materiał i metody: Badaniem objęto 31 chorych z wielomiejscowymi zmianami zwyrodnieniowymi w układzie ruchu. W terapii stosowano 2 metody usprawniania: grupa I - fizykoterapia tradycyjna i kinezyterapia - ćwiczenia w wodzie $(n=18)$, grupa II - krioterapia i kinezyterapia $(n=13)$. Pacjentki były badane 3-krotnie: przed rozpoczęciem leczenia, po 4 tygodniach rehabilitacji i po 3 miesiącach od zakończenia usprawniania. Zastosowano kwestionariusz GHQ-28 oceniający stan psychiczny, kwestionariusz SF-36 do oceny jakości życia oraz codzienną subiektywną ocenę nasilenia bólu. Wyniki badań zostaty poddane analizie statystycznej.

Wyniki: Na podstawie kwestionariusza subiektywnej oceny nasilenia bólu wykazano porównywalne w obu grupach zmniejszenie procentowego nasilenia bólu. Ból ulegt redukcji w obu grupach badawczych także wg kwestionariusza SF-36, a zmniejszenie dolegliwości bólowych utrzymywało się w obu grupach po 3 miesiącach od zakończenia leczenia. Na podstawie kwestionariusza GHQ-28 stan psychiczny i emocjonalny badanych pacjentek po rehabilitacji, zarówno leczonych ćwiczeniami w wodzie (I), jak i po krioterapii (II), wyraźnie się poprawit. W grupie I bezpośredni efekt po leczeniu był wyraźny, po 3 miesiącach poprawa ustępowała, ale stan chorych nie powracał do wyjściowego, natomiast w grupie II następowała wyraźna i trwała poprawa zdrowia.

\section{Address for correspondence:}

Ewa Gaszewska PhD, Clinic of Rehabilitation in Rheumatology Prof. Eleonora Reicher's Institute of Rheumatology in Warsaw, ul. Spartańska 1, 02-637 Warszawa, Poland, tel./fax +48 2284191 91, tel. +48 2264678 92, e-mail: ewa.gaszewska@ir.ids.pl Submitted: 11.02.2013 
Conclusions: Comprehensive rehabilitation in osteoarthritis, regardless of the strategy used reduces pain and has a beneficial effect on patients' emotional and psychological well-being. A reduction in pain severity was associated with improved psychological and emotional functioning.

\section{Introduction}

Degenerative joint disease (also referred to as osteoarthritis [OA]) is a chronic non-inflammatory joint disorder of multifactor etiology and progressive nature. OA is the most common pathology of the joints, resulting from an imbalance between processes of regeneration and degeneration of articular cartilage and subcartilaginous tissue. OA manifests with joint stiffness, progressive loss of movement and impaired joint function [1-3].

Pain is the main symptom in OA; it intensifies during activities involving weight bearing and, initially, subsides after a period of rest. During the course of the disease, the pain becomes continuous and occurs also at night, which disturbs sleep. Chronic pain that increases with physical activity makes everyday activities harder, and often causes depressed mood [1, 2, 4].

Motor impairment and the associated pain affect the patient's psychological and emotional well-being, which may lead to periods of depression, uneasiness, anxiety and keeps the patient in chronic distress. This affects the patients' functioning within their family as well as their professional and social life. Inability to fulfill the tasks and expectations of the patients' social and cultural environment keeps them in a state of chronic distress and lowers their quality of life $[2,4,5]$.

The term "quality of life" encompasses both an objective health assessment and a subjective impression. The patients' general condition, physical capacity, and fitness level that are subject to evaluation combine with the patients' subjective impressions and experiences stemming from everyday life. The quality of life in the psychological realm depends on the individual's condition, personality traits, needs, values, and environmental/situational factors, which constantly affect the individual and which are subject to his/her evaluation. This evokes specific emotions, whether motivating or demotivating, which may be a cause of distress. Every disease and its treatment are associated with some obstacles in meeting the person's needs, which evokes emotional reactions, such as anxiety, denial, anger, depressed mood; also, it is a cause of discomfort and disturbs the feeling of happiness [4-8].

Emotions are strong feelings of clearly positive or negative quality that are preceded by an event and are directional in nature. The processes of development, duration, and decline of emotions are only to a small degree subject to our will. However, they are always conscious phe-
Wnioski: Kompleksowa rehabilitacja w chorobie zwyrodnieniowej stawów, bez względu na zastosowane metody usprawniania, redukuje ból oraz wpływa korzystnie na stan emocjonalny i psychiczny chorych. Poprawa w obszarach życia psychicznego i emocjonalnego następowała wraz z ustępowaniem dolegliwości bólowych.

nomena. According to Frida, the mechanisms that control these processes are based on experience and impose prespecified responses to stimuli, as well as determining readiness for action. Emotions cannot be separated from other aspects of the human psyche, and are closely associated with our motivations, needs, attention, perception, information processing, and communication $[9,10]$.

Comprehensive rehabilitation is a form of integrated, intensive rehabilitation. This includes all possible kinesiotherapy techniques, selected physiotherapy procedures, hydrotherapy, and massages. Comprehensive rehabilitation also includes psychotherapy and, sometimes, if appropriate, social care, or occupational rehabilitation. Comprehensive rehabilitation involves the use of modern, evidence-based rehabilitation techniques, including conventional kinesiotherapy and manual therapy, especially soft tissue therapy techniques complemented with physical therapy in its conventional as well as its state-of-the-art forms such as systemic cryotherapy. Physical exercises and procedures combined into a comprehensive rehabilitation course are an integral part of treatment in patients with multiple degenerative lesions, and are typically the main treatment strategy in OA [11].

The objectives of this study are to evaluate the influence of the comprehensive rehabilitation on mental and emotional well-being and the quality of life in female patients with multiple musculoskeletal degenerative lesions in the movement system. Few fact-based studies on mental and emotional well-being have been undertaken so far. Studies on female patients suffering from osteoarthritis are carried out with the help of polls which supply objective information on their mental well-being. They help evaluate properly whether and how deeply various rehabilitation methods influence emotions and quality of life, understood not only as the physical condition but above all mental well-being.

The quality of life, which depends on health, is difficult to define due to the fact that this term is abstract. Levine defined quality of life as "the part of human life which applies directly to an individual being important simultaneously" [12].

\section{Material and methods}

Female patients with stable multiple-site OA were included in this study. This research program was approved by the Local Ethics Committee. 
The group of 31 subjects with OA [i.e. 18 patients (group I) scheduled for exercises in the pool and 13 patients (group II) who underwent cryotherapy] was examined three times. All subjects underwent kinesiotherapy in the form of individual exercises, group exercises, and exercises using of special equipment. The mean age of patients in group I was 59.1 and in group II -55.6 years. A total of 6.6 joints in group I patients and 7.2 joints in group II patients showed evidence of OA. The disease duration was longer in group I at 12.3 years, which correlated with the patients' age, whereas disease duration in group II patients, who underwent cryotherapy, was 10.6 years (Table I).

The inclusion criteria were: patients meeting the ACR criteria diagnosis for $\mathrm{OA}$; the presence of pain and dysfunction at 4 or more sites (a large joint or a set of small joints); patient age (35 to 65 years); written informed consent; psycho-physical ability to subjectively assess pain severity and complete standard questionnaires (SF-36 v. 2, David Goldberg's General Health Questionnaire [GHQ-28]); and a lack of contraindications for comprehensive rehabilitation. Patients with advanced degenerative lesions of intervertebral and peripheral joints that required surgical treatment were excluded from the study. No female patients were given either oral steroid therapy or injections. Some patients were given to NSAIDs periodically. Patients had an opportunity to consult a psychologist specialist during the rehabilitation. None of them required psychological treatment.

All study subjects provided their informed consent (having read the objectives and methods of the study). Comprehensive rehabilitation was conducted for a period of 4 weeks. Depending on the applied rehabilitation techniques, the patients were divided into two groups: group I and group II [cryotherapy twice every day, including systemic cryotherapy (cryogenic chamber) and local cryotherapy for selected joints]. All study subjects underwent kinesiotherapy in the form of individual and group therapeutic exercises, as well as exercises using of special equipment. Each patient was examined three times: prior to treatment, 4 weeks into her rehabilitation course, and 3 months after its completion. Data from each patient's medical history, medical records, and physical examination were recorded in a specially prepared case report form (CRF), complemented with the patient's med- ical records. The following parameters were evaluated: subjective pain severity at baseline before initiating rehabilitation and subsequently for a period of 4 weeks (on each of the 20 procedure days), and the patient's general condition according to GHQ-28 and SF-36 v. 2 questionnaires.

The General Health Questionnaire (GHQ-28) was used in this study to determine mental dysfunctions in patients with a chronic condition, such as OA.

The SF-36 questionnaire evaluates the physical and mental health status. The SF-36 enables one to find the differences resulting from the use of various therapies in patients with a particular disorder and provides information on the patient's general condition in eight scales: physical functioning, physical role functioning, bodily pain, general health perceptions, vitality (energy and fatigue), social role functioning, emotional role functioning, and mental health (mental suffering).

\section{Statistical analysis}

The statistical analysis was conducted with SAS 9.2. Values of measurable parameters of normal distribution were presented as means and standard deviations. Measurable parameters of irregular distribution were presented as medians and interquartile ranges. The KolmogorovSmirnov test was used to test the distribution of quantitative variables against normal distribution. The paired and unpaired Student's t tests (for two independent and two dependent samples, respectively) were used to compare the statistical significance of differences between means. The non-parametric Mann-Whitney test (for two independent samples) or the Wilcoxon rank-sign test (two dependent samples) was used to estimate the statistical significance of differences between medians. The significance level of $\alpha \leq 0.05$ was used to test the null hypothesis. Two-sided tests were used.

\section{Results}

The results of a pain assessment questionnaire demonstrated a comparable drop in pain severity (\%) in both groups (Fig. 1). Patients from the cryotherapy group experienced aggravated pain on day 2 and 3, which subsequently gradually subsided, reaching a plateau after day 17 .

Table I. The data of female patients participating in the research program

\begin{tabular}{|lccc|}
\hline Parameters & Group I hydrotherapy & Group II cryotherapy & $p$-value \\
\hline Age (in years) & $59.1(45-64)$ & $55.6(47-63)$ & NS \\
\hline The number of affected joints & $7.2(4-13)$ & $6.6(4-13)$ & NS \\
\hline Period of disease (in years) & $12.3(1-30)$ & $10.6(5-30)$ & NS \\
\hline The number of female patients in the group & 18 & 13 & - \\
\hline
\end{tabular}


Patients from the hydrotherapy group experienced an initial reduction in pain and their pain severity also stabilized starting on day 17 . Both groups showed a comparable decrease in pain severity (by $60 \%$ vs. baseline). No significant differences in pain reduction between groups I and II were observed after 4 weeks of rehabilitation.

Based on the four subscales of GHQ-2, the following parameters were evaluated: $\mathrm{A}$ - somatic symptoms; $\mathrm{B}$ - anxiety, insomnia; C - functional disorders/social dysfunction; D - depressive symptoms. In both groups, physical symptoms subsided considerably, with the improvement clearly persisting after 3 months of therapy completion. Moreover, group II patients reported a continued reduction in anxiety at 3 months. Group II (systemic cryotherapy) patients experienced a clear, statistically significant improvement in insomnia, their feeling of unhappiness considerably decreased, with continuous -though less dynamic - improvement at 3 months after therapy completion. No significant differences were observed in group I. The feeling of social inadequacy decreased in both groups, with a clearer and more significant improvement noted in group I. The improvement observed in both groups 3 months following therapy was still present but not at the same level as that observed immediately following therapy. Patients of either group exhibited no problems with their sense of identity. A slight difference in assessments indicates that rehabilitation helps enhance the sense of identity. According to scale D results at screening, the study population showed no mental disorders. The study subjects' general emotional state was evaluated based on pooled GHQ-28 results (scales A, B, C, D). Following rehabilitation, OA patients from both groups exhibited improvement in psychophysical and general health scores. Group I clearly demonstrated direct posttherapy effects, with a decrease in improvement (although not to the baseline level) observed after 3 months. Conversely,

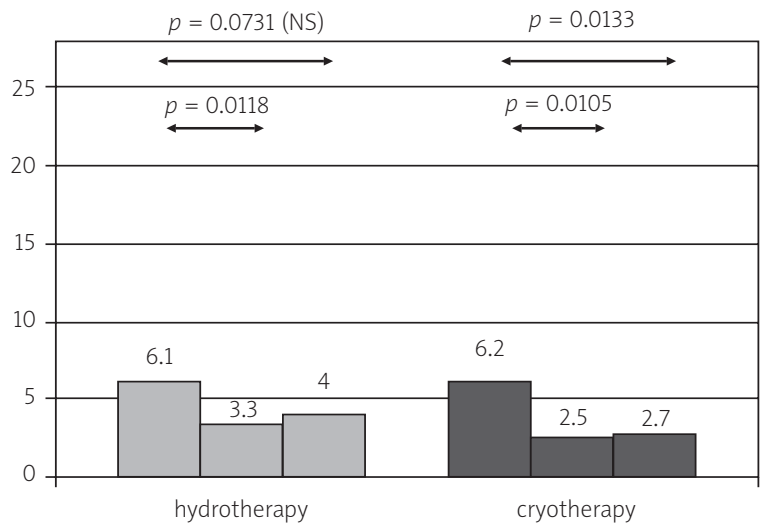

Fig. 2. Summary results from the GHQ - 28 test. Dependencies of the individual general health sensation from the somatic condition, before the beginning of rehabilitation, after 4-weektreatment and after 3 months upon completing the treatment. (The less the better).

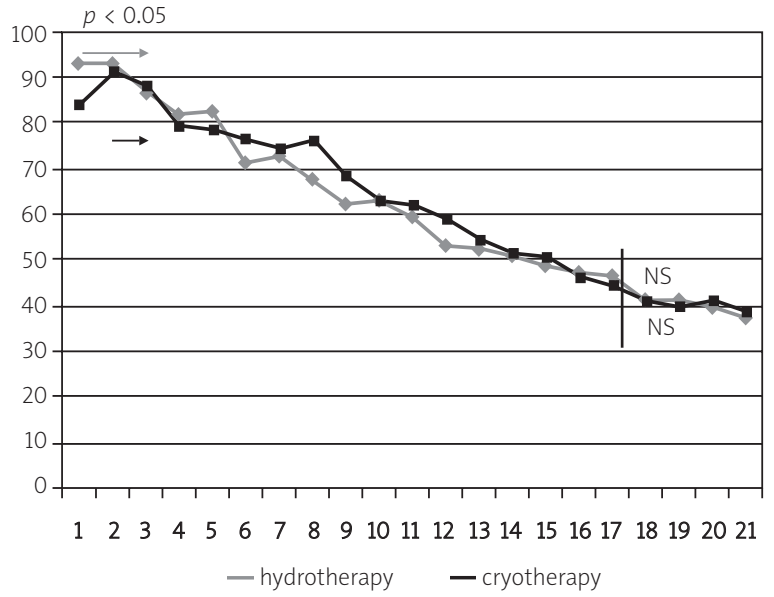

Fig. 1. The level (in \%) of sensing the pain by the female patients suffering from osteoarthritis for 21 next days of comprehensive rehabilitation.

group II experienced a significant and sustained improvement in health (Fig. 2).

The SF-36 yielded general condition data from 8 scales. The physical health measure (including physical functioning, physical role functioning, and pain scores) remained at the same level with a tendency to deteriorate after 3 months. Conversely, the perceived mental health measure (including vitality, social functioning, emotional role functioning scores) increased (in group I - significantly) directly after the end of therapy; however it decreased slightly after 3 months without dropping back to baseline values. The changes in none of the discussed parameters were statistically significant. It is worth emphasizing that there was no evidence of mental or behavioral disturbances in the given group (Fig. 3).

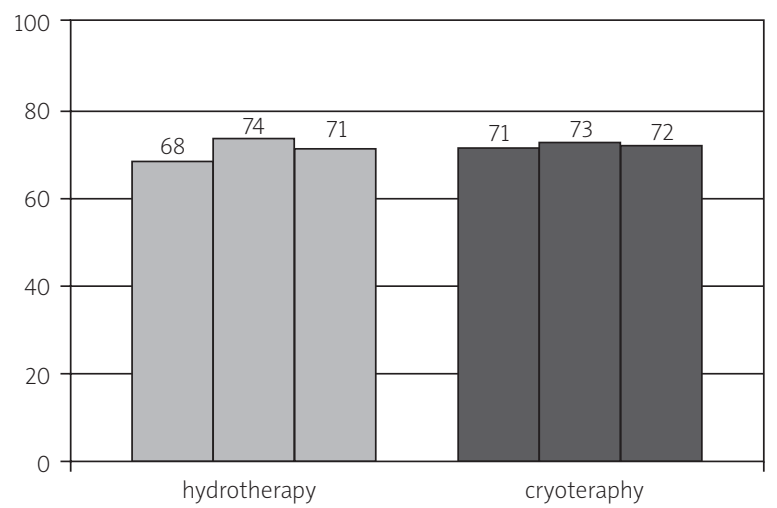

Fig. 3. Summary results from the mental wellbeing part of the SF-36 test. Dependencies of the mental well-being from the somatic condition, before the beginning of rehabilitation, after 4-weektreatment and after 3 months upon completing the treatment. (The more the better). 


\section{Discussion}

Osteoarthritis (OA) has been affecting more and more people. Thus, it is important to find a way to combat not only physical dysfunction, but also poor mental condition of OA patients. The issues of patients' pain and poor motor performance as well as evaluation of patients' physical condition are currently being addressed. An analysis of the results confirmed beneficial effects of rehabilitation in the treatment of spinal and peripheral OA, which was consistent with previously published results [13]. A wide spectrum of physical procedures, such as ultrasounds, magnetic fields, laser therapy, electrotherapy, and local cryotherapy in combination with kinesiotherapy, have been used [14-19]. Systemic cryotherapy plays a noteworthy role in improving motor dysfunction, particularly in pain alleviation. Systemic cryotherapy in combination with kinesiotherapy helped substantially reduce pain and improve the psychophysical status of study subjects, which was observed both 4 weeks into the course of rehabilitation and 3 months after its conclusion. The fact that cryotherapy has been considered to be a therapeutic process by other authors [19-22] confirms its positive impact on the general quality of life. Both study groups showed a reduction in pain intensity by $60 \%$ of the baseline level, which has been shown in a subjective pain assessment chart and confirmed by SF-36 results. Both studied therapies are effective tools in the fight against pain. Rehabilitation with aquatic exercises brings improvement in the performance status of patients with musculoskeletal degenerative lesions, which has been confirmed by the results of other studies $[13,18,19]$.

The presence of pain and physical dysfunction is inseparably associated with the patient's emotional and mental status, which is consistent with the results of the GHQ-28, where an improvement in somatic symptoms resulted in an improvement in psychological state of the study subjects. The use of the GHQ-28 in studies evaluating the effects of the psyche on the quality of life confirms the questionnaire's usefulness in research studies [20-24].

Deterioration of somatic symptoms causes an increase in psychological anxiety that the patient experiences. OArelated symptoms are associated with the development of unpleasant feelings of anxiety, uncertainty, and magnified insomnia. We observed that physical symptoms, including pain, were noticeably reduced after rehabilitation. A somatic condition, such as OA magnifies feelings of unhappiness; moreover, it stands in the way of reaching a complete contentment with life and meeting one's needs and desires. Group II patients experienced a considerable improvement involving a substantial reduction in their anxiety and sleeplessness, with this reduction still continuing, though less rapidly, 3 months after therapy. The improvement observed in group I was lesser. Alleviation of somat- ic symptoms reduces anxiety, eliminates insomnia and, as a consequence, significantly improves the quality of life. A similar association was suggested in other studies using the GHQ-28 [23-25]. Those affected by a somatic condition associated with pain and musculoskeletal dysfunction experience difficulties in normal functioning in all the aspects of social life. The feeling of social inadequacy decreased in both study groups; this time, a more pronounced and statistically significant reduction was observed in group I. Aquatic exercises mentioned by other authors help improve physical fitness, and alleviate anxiety and insomnia [18, 19].

Neither group exhibited problems with identity; there were no disturbances in awareness of one's own characteristics or one's separateness. A slight difference in assessments indicates that rehabilitation helps enhance the sense of identity. Also, no mental disorders were detected in the study population $[8,10]$.

An analysis of the SF-36 demonstrates an improvement, though non-significant, in all evaluated areas. This was observed mainly in terms of pain severity, emotional role functioning and is expressed in the form of improved psychological well-being. These findings are consistent with those from other studies on the effects of rehabilitation on improving the quality of life in OA patients [16, 18, 19].

There is a clear analogy between the results of the GHQ28 and those of the SF-36 in the mental health measure of the latter, which comprises vitality, social functioning and emotional role functioning scores. Improvement, which was statistically significant in group I, was observed immediately after completion of therapy and, 3 months later, the improvement diminished slightly without reaching the baseline scores. It is noteworthy that no group demonstrated any manifestations of mental or behavioral disorders.

In summary, the psychophysical status of study subjects from both groups as well as the subjects' impression of general health improved after the rehabilitation. The previous preliminary studies show beneficial effects of comprehensive rehabilitation on the female patients' psychophysical status. Further detailed studies on larger group of female patients are needed to confirm clearly the beneficial rehabilitation effect on the female patients' psychophysical status.

\section{Conclusions}

- Comprehensive rehabilitation in patients with OA has a beneficial effect on the patients' psychological well-being and the quality of life.

- Both cryotherapy and aquatic exercises have an impact on considerable pain reduction to a comparable extent and at comparable rates, on average by $60 \%$ of the baseline level. An improvement in pain severity was associ- 
ated with improved psychological and emotional wellbeing of the patients.

- The greatest improvement involved alleviation of psychological anxiety, diminished feelings of unhappiness and social inadequacy in both study groups, with greater improvement observed in the cryotherapy group.

- Our results confirm the association between female osteoarthritis patients' psychological well-being and their somatic health.

\section{Authors declare no conflict of interest.}

\section{References}

1. Klimiuk PA, Kuryliszyn-Moskal A. Choroba zwyrodnieniowa stawów. Reumatologia 2012; 50: 162-165.

2. Sierakowska M, Sierakowski S, Wróblewska M, Krajewska-Kułak E. Problemy zdrowotne pacjentów z chorobą zwyrodnieniową stawów i ich wpływ na jakość życia uwarunkowaną stanem zdrowia. Reumatologia 2010; 48: 372-379.

3. Styczyński T. Leczenie bólu w chorobach reumatycznych. Przewodnik Lekarza 2006; 1: 78-82.

4. Trzebiatowski J. Jakość życia w perspektywie nauk społecznych i medycznych systematyzacja ujęć definicyjnych. Hygeia Public Health 2011; 56: 25-31.

5. Papuć E. Jakość życia - definicje i sposoby jej ujmowania. Curr Probl Psychiatry 2011; 12: 141-145.

6. Ware JE, Kosinski M, Dewey JE. How to score Version 2 of the SF-36 Health Survey, Medical Outcomes Trust and Quality Metric Incorporated. Lincoln, RI 2002.

7. Żołnierczyk-Zreda D, Wrześniewski K, Bugajska J, Jędryka-Góral A. Polska wersja kwestionariusza SF-36v2 do badania jakości życia. CIOP-BIP, Warszawa 2009.

8. Willand P, Madej M, Szmyrka-Kaczmarek M. Monitorowanie stanu pacjenta w chorobach reumatycznych. Górnicki Wydawnictwo Medyczne, Wrocław 2008: 75-89.

9. Rybakowski J, Pużyński S, Wciórka J. Psychiatria. Podstawy psychiatrii, t. 1. Elsevier Urban \& Partner, Wrocław 2010.

10. Frida NH. The Emotions. Cambridge University Press, 1986: 9-109, 453-473.

11. Księżopolska-Orłowska K. Postępowanie rehabilitacyjne w reumatologii. Reumatologia 2012; 50: 181-184.

12. Levine NM. Incorporation of quality-of-life assessment into clinical trials. In: Effect of cancer on quality of life. Osoba D (ed.). CRC Press, Boston 1991: 105-111.

13. Ciejka E, Wójtowicz K. Ocena skuteczności stosowanych zabiegów fizjoterapeutycznych $w$ leczeniu choroby zwyrodnieniowo-wytwórczej stawów obwodowych i kręgosłupa. Balneologia Pol 2009; LI: 189-193.

14. Concalves RS, Cabri J, Pinheiro JP. Evaluation of patient characteristics as predictors of health status in knee osteoarthritis patients referred for physical therapy. Acta Reumatol Port 2011; 36: $137-144$.

15. Pua YH, Liang Z, Ong PH, et al. Associations of knee extensor strength and standing balance with physical function in knee osteoarthritis. Arthritis Care Res 2011; 63: 1706-1714.

16. Chmielewska D, Wawrzyńczyk J, Kubacki J i wsp. Ocena efektywności fizjoterapii w zmianach zwyrodnieniowych stawów biodrowych wyrażona samooceną jakości życia. Index Copernicus 2012; 12: 59-70.

17. Sieroń A, Pasek J, Mucha R. Krioterapia w rehabilitacji. Rehabilitacja w Praktyce 2007; 3: 24-36.

18. Ridan T, Puszczałowska-Lizis E, Mirek M. Łączny wpływ kinezyterapii oraz zabiegów z użyciem borowiny i wód siarczkowo-siarkowodorowych na wybrane parametry funkcjonalne narządu ruchu oraz dolegliwości wynikające z choroby zwyrodnieniowej stawów biodrowych. Acta Balneol 2011; 13: 43-50.

19. Sukenik S. Balneologia w regionie Morza Martwego w leczeniu zapalnych i niezapalnych schorzeń reumatologicznych. Balneol Pol 2008; L: 19-20.

20. Goldberg D, Williams P, Makowska Z, Merecz D. Ocena zdrowia psychicznego na podstawie badań kwestionariuszami Davida Goldberga. Instytut Medycyny Pracy, Łódź 2001.

21. Hyphantis T, Floros GD, Goulia P, et al. The Life Style Index: correlations with psychological distress and hostility. Psychiatrike 2011; 22: 207-220.

22. Goli M, Sese A, Serrano MJ, et al. Mental disorders, chronic conditions and psychological factors: a path analysis model for healthcare consumption in general. Int Rev Psychiatry 2011; 23: 20-27.

23. Alvares C. Is there room for improvement in the Spanish version of the scaled General Heath Questionnaire (GHQ-28). Aten Primaria 2011; 43: 6620-6627.

24. Taylor-Gievre JA, Nair B, Skomro R, Lim HJ. Components of sleep quality and sleep fragmentation in rheumatoid artritis and osteoarthritis. Musculoskeletal Care 2011; 9: 152-159. 